\title{
PENERAPAN PERSONAL SELLING PADA STRATEGI PEMASARAN CV SURYA GEMILANG MOTOR (CABANG WULUHAN KABUPATEN JEMBER)
}

\author{
SAMPIR ANDREAN SUKOCO* \\ MUHAMMAD CINDIKA PUTRA EMAS GUSTIAWAN \\ Program Studi Ilmu Administrasi Niaga \\ Sekolah Tinggi Ilmu Administrasi Pembangunan Jember \\ *Email: andre@stiapembangunanjember.ac.id
}

\begin{abstract}
ABSTRAK
Personal selling merupakan presentasi pribadi oleh seorang sales dengan tujuan melakukan penjualan dan meningkatkan hubungan yang baik dengan para konsumen, baik itu konsumen yang sudah lama maupun konsumen yang masih baru. Sales melakukan komunikasi langsung kepada konsumen dengan menawarkan produknya. Penelitian ini membahas tentang penerapan personal selling yang dilakukan oleh CV Surya Gemilang Motor Cabang Wuluhan dalam menawarkan produk motor honda yang dijual.

Metode penelitian ini menggunakan metode kualitatif studi kasus dengan cara mendeskripsikan apa yang dilakukan oleh CV Surya Gemilang Motor Cabang Wuluhan dalam menerapkan personal selling. Teknik penentuan informan menggunakan metode purposive, informan untuk penelitian ini berjumlah 3 orang yang dipilih peneliti karena memiliki kompetensi dibidangnya. Pengumpulan data dilakukan melalui observasi, wawancara, dan dokumentasi. Metode analisis data dilakukan dengan tiga cara yaitu Data Condensation, Data Display, dan Conclusion Drawing atau Verifications.

Hasil dari penelitian ini menunjukkan bahwa CV Surya Gemilang

Motor Cabang Wuluhan menerapkan personal selling pada strategi pemasarannya. Tahap-tahap yang dilakukan adalah memilih dan menilai prospek dengan cara kanvas, melakukan pra pendekatan kepada prospek terlebih dahulu, setelah itu melakukan pendekatan, melaksanakan presentasi/demontrasi kepada prospek tentang keunggulan motor honda, handling objection, melakuan sales closing ketika sudah presentasi/demontrasi, dan juga yang terakhir melakukan follow up kepada prospek.
\end{abstract}

Kata Kunci: Personal Selling, Strategi Pemasaran 


\section{PENDAHULUAN}

Perusahaan yang bergerak maju akan melakukan suatu manajemen organisasi yang baik. Manajemen pada tingkat produksi, keuangan, sumber daya manusia sampai pada tingkat pemasaran. Sedangkan untuk memasarkan produk yang dihasilkan oleh perusahaan dengan baik, sangat diperlukan suatu manajemen pemasaran yang benar.

Tujuan yang ingin dicapai oleh suatu perusahaan tentu yang paling utama adalah penjualan yang baik. Proses penjualan adalah kunci, dan pemasaran adalah suatu jalan untuk mewujudkannya. Dalam proses penjualan, terdapat suatu teori penjualan personal (personal selling) yang dapat dilakukan perusahaan untuk meningkatkan penjualan produknya. Penjualan personal sudah jamak dilakukan oleh beberapa perusahaan.

Personal selling merupakan presentasi personal oleh tenaga penjual perusahaan dengan tujuan melakukan penjualan dan membangun hubungan yang baik dengan para konsumen, baik itu konsumen yang sudah lama maupun konsumen yang masih baru. Personal selling ini bisa disebut alat promosi yang bersifat lisan, baik kepada seseorang ataupun calon pembeli dengan maksud untuk menciptakan timbulnya transaksi pembelian yang pada dasarnya saling menguntungkan bagi penjual dan bagi pembeli (Kotler dan Armstrong, 2008:182).

Persaingan bisnis adalah sesuatu yang harus bisa diterima oleh semua perusahaan. Baik perusahaan yang menjual produk yang sama maupun yang menjual produk yang berbeda. Kita saat ini dapat melihat banyaknya perusahaan yang menjual produk yang sama. Sebagaimana contoh industri usaha sepeda motor saja. Persaingan yang sangat ketat antara penjual sepeda motor sudah biasa terjadi. Secara umum kita mengenal merek motor yang dipasarkan di Indonesia seperti Honda, Yamaha, Suzuki, dan Kawasaki saling bersaing untuk memperebutkan hati konsumen. Para perusahaan melakukan berbagai macam strategi termasuk melakukan 
personal selling untuk dapat menjual produknya.

Penjualan motor honda yang baik tidak terlepas dari kekuatan personal selling-nya. Meskipun hal tersebut bukan menjadi faktor utama, tetapi kekuatan penjualan sales dapat dikatakan salah satu faktor yang membuat penjualan motor honda bagus. Penjualan yang baik memang terdiri dari banyak faktor, bisa dari kualitas produk bagus, tempat distribusi yang baik, toko penjualan yang banyak tersedia, dan tidak terlepas dari pemasaran personal selling tadi.

Toko tempat menjual motor honda biasa disebut dengan dealer. Dealer honda sendiri di Jawa Timur dibagi menjadi 2 jenis. Pertama adalah main dealer, yaitu toko/dealer resmi yang menjual motor honda. Dealer resmi di jawa timur ini dipegang oleh PT Mitra Pinasthika Mustika (PT MPM) yang mendistribusikan motor honda ke dealer-dealer daerah. Kedua adalah sub dealer. Sub dealer merupakan toko yang menjual motor honda tetapi kepemilikannya perorangan.
Biasanya didaerah-daerah Kabupaten banyak yang berbentuk $\mathrm{CV}$.

Pada Kabupaten Jember sendiri tempat dimana penelitian akan dilakukan juga terdapat banyak sekali dealer motor honda. Sama dengan penjelasan diatas, bahwa dealer di Jember juga menjadi 2 jenis, yaitu main dealer dan sub dealer. Main dealer yang menjual motor di Kabupaten Jember diantaranya MPM Diponegoro dan MPM Kebonsari, sedangkan sub dealer yang ada diantaranya SGM, SMM, Sekawan, Gunawan, Jaya Abadi dan KSM. Terdapat 8 dealer yang menjual motor honda di Kabupaten Jember. 2 main dealer (dealer resmi) dan 6 sub dealer (dealer yang bisa dimiliki perorangan).

CV Surya Gemilang Motor (SGM) merupakan dealer yang memiliki 5 cabang yang ada di Provinsi Jawa Timur. Cabangnya ada di Surabaya, Lamongan, Jember, Bojonegoro, dan Malang. Cabang Jember lokasinya berada di Jl. Gajah Mada No. 30 Rambipuji Jember. Dealer CV Surya Gemilang Motor cabang Jember sendiri memiliki 2 
pos (cabang kecil) yang terletak di Kecamatan Wuluhan dan Kecamatan Tempurejo.

CV Surya Gemilang Motor Cabang Wuluhan berada di Jl Raya Kesilir No 73 Desa Kesilir Kecamatan Wuluhan. Produk yang dijual oleh CV Surya Gemilang Motor Cabang Wuluhan juga sama dengan yang dijual dealer honda lain, yaitu motor berbagai jenis honda seperti matic, cup, dan sport. Dealer SGM Cabang Wuluhan sendiri memiliki 4 sales dan 1 koordinator sales, diantaranya adalah Fauzi, Ade, Gogon, dan Yayan dan 1 koordinator yang bernama Heru Mustofa. Cabang Wuluhan ini mulai dibuka pada tahun 2009 dan masih eksis sampai saat ini.

Penjualan dari cabang dealer ini dari periode bulan Oktober, November dan Desember 2019 berjumlah 110. Sebenarnya target yang diberikan oleh CV Surya Gemilang Motor cabang Jember perbulan adalah 50 unit motor. Berarti total target dalam 3 bulan seharusnya adalah 150 unit penjualan.
Tabel 1. Penjualan CV Surya Gemilang Motor Cabang Wuluhan Total

\begin{tabular}{cccc} 
No & Bulan & Tahun & Penjualan \\
\hline 1. & Oktober & 2019 & 35 \\
2. & November & 2019 & 38 \\
3. & Desember & 2019 & 37 \\
\hline
\end{tabular}

Sumber : Surya Gemilang Motor Cabang Wuluhan

Jumlah penjualan tersebut hanya 110, tidak memenuhi target yang diberikan oleh CV Surya Gemilang Motor cabang Jember yang berjumlah 150 unit dalam 3 bulan. Fenomena jumlah target yang tidak terpenuhi inilah yang menjadi suatu permasalahan yang patut untuk diteliti. Faktor apakah yang menyebabkan cabang Wuluhan ini sulit untuk bisa mencapai target dalam kurun waktu 3 bulan tersebut.

Penjualan motor honda sangat dipengaruhi oleh kemampuan sales untuk menjual produknya. Sales pada dealer merupakan ujung tombak yang menawarkan produk kepada konsumen. Semua dealer honda di Kabupaten Jember tidak ada yang berbeda dalam menjual kualitas maupun variasi produk, karena semua produk honda yang dijual adalah produk yang sama. Produk 
yang dijual sama, dan yang membedakan dengan dealer lain hanyalah kemampuan personal selling para salesnya. Bagaimana proses personal selling yang dilakukan sehingga tidak dapat mencapai target yang ditetapkan. Oleh karena itu, penelitian ini secara spesifik mempelajari personal selling

\section{TINJAUAN PUSTAKA}

\subsection{Manajemen Pemasaran}

Istilah manajemen adalah suatu proses yang berbeda terdiri dari planning, organizing, actuating dan controlling yang dilakukan untuk mencapai tujuan yang ditentukan dengan menggunakan manusia dan sumber daya lainnya. Dengan kata lain, berbagai jenis kegiatan yang berbeda itulah yang membentuk manajemen sebagai suatu proses yang tidak dapat dipisah-pisahkan dan sangat erat hubungannya (Herujito, 2001:3).

Menurut Sudarsono (2019:3) pemasaran adalah keseluruhan dari kegiatan bisnis atau yang ditujukan untuk merencanakan, menentukan harga, mempromosikan dan mendistribusikan barang dan jasa yang dilakukan CV Surya Gemilang Motor Cabang Wuluhan. Berdasarkan latar belakang diatas, maka rumusan masalah penelitian ini adalah "Bagaimana Penerapan Personal Selling Pada Strategi Pemasaran CV Surya Gemilang Motor Cabang Wuluhan?”.

yang memuaskan kebutuhan baik kepada pembeli yang ada maupun pembeli potensial.

Menurut Cannon dkk (2008:39) proses manajemen pemasaran merupakan proses perencanaan aktivitas pemasaran, pengarahan implementasi rencana-rencana tersebut, dan pengelolaan dari rencana tersebut. Perencanaan, implementasi, dan pengelolaan merupakan poin-poin yang dibahas dalam manajemen pemasaran. Perencanaan strategi pemasaran artinya menemukan berbagai peluang menarik dan menyusun strategi pemasaran yang menguntungkan. 


\subsection{Bauran Pemasaran}

Bauran pemasaran merupakan sebuah proses dari pemasaran. Menurut Suwarno (2011:171) setiap perusahaan tentu saja melakukan proses pemasaran. Proses inilah yang menjadikan barang dari produsen bisa sampai ke tangan konsumen. Perlu adanya strategi khusus dalam menjalankan proses ini. Fokus kegiatan ini adalah konsumen. Pelayanan konsumen diperhatikan sebaik mungkin demi mencapai keberhasilan pemasaran. Strategi yang biasa digunakan adalah bauran pemasaran.

Bauran pemasaran adalah campuran dari variabel-variabel pemasaran yang dapat dikendalikan, digunakan oleh suatu perusahaan untuk mengejar tingkat penjualan yang diinginkan dalam pasar sasaran. Menurut Alma (2014:202) para pengusaha yang kreatif, akan selalu menciptakan kombinasi yang terbaik dari elemen $4 \mathrm{P}$ yang menjadi komponen bauran pemasaran. Mereka harus menciptakan dari masing-masing elemen $\mathrm{P}$ yang mana yang paling baik, dan paling banyak digunakan dalam strategi pemasarannya. Antara promosi dan produk, tidak dapat dipisahkan dan saling berangkulan untuk suksesnya pemasaran. Disini harus ada keseimbangan, produk baik, sesuai dengan selera konsumen, bersamaan dengan teknik promosi yang tepat akan sangat membantu suksesnya usaha pemasaran. Disitulah peran dari bauran pemasaran itu sendiri.

\subsection{Bauran Promosi}

Bauran promosi adalah elemen bauran pemasaran dalam ilmu manajemen pemasaran. Promosi menjadi bagian yang tidak dapat dipisahkan pada sebuah fenomena pemasaran. Sudah tentu tanpa adanya promosi, maka perusahaan tidak akan bisa berjalan sama sekali.

Menurut Stanton (1989) bauran promosi adalah kombinasi dari personal selling, periklanan, publisitas, pemasaran langsung, dan promosi penjualan yang dapat membantu perusahaan untuk mencapai tujuan. Oleh karena itu bauran promosi merupakan tugas dari suatu perusahaan dalam cara mendistribusikan total keseluruhan 
anggaran promosi melalui lima alat promosi diatas.

\subsection{Personal Selling}

Personal selling adalah aktivitas dari personal yang dilakukan oleh seorang tenaga penjual dengan tujuan untuk menarik pelanggan, menjual, dan membangun interaksi dengan pelanggan. Dalam kegiatan ini terjadi interaksi atau hubungan langsung antara seorang tenaga penjual dengan pelanggannya.

Elemen personal selling ini dalam interaksinya lebih dominan untuk mempengaruhi atau membujuk seorang pelanggan. Perlu diketahui bahwa personal selling ini jika dibandingkan oleh bauran promosi lainnya lebih fleksibel karena seorang tenaga penjual bisa dengan cepat untuk segera dapat merespons atau dapat menyesuaikan gaya serta komunikasi yang dilakukan sesuai dengan karakter dan keinginan pelanggan. Tenaga penjual dalam hal ini dapat dengan cepat mendapatkan feedback dari seorang pelanggan, serta dengan cepat pula dapat merespon pelanggan dengan baik (Suryani, 2017:189).
Handini dkk $(2019: 138)$ menegaskan hal yang sama bahwa penjualan personal melibatkan tenaga penjualan yang berinteraksi secara langsung dengan calon konsumen dengan menjelaskan manfaat produk perusahaan. Dibandingkan dengan elemen bauran promosi lainnya, penjualan personal merupakan cara komunikasi yang paling tepat karena ditujukan secara langsung kepada konsumen prospektif. Tujuan dari penjualan personal ini adalah untuk mencari prospek, memberi informasi kepada prospek, persuasi prospek untuk membeli suatu produk, dan mempertahankan dari kepuasan pelanggan melalui pelayanan purna jual.

Menurut Cannon dkk (2009:103), penjualan personal ini mutlak sangat diperlukan dalam paduan promosi pada sejumlah perusahaan. Penjualan personal ini merupakan pengeluaran operasional paling terbesar dari perusahaan. Ini merupakan salah satu alasan penting lain untuk memahami berbagai keputusan manajemen penjualan. Menurut Simamora (2003:297) ada 
tiga manfaat penjualan personal yaitu:

a. Berhadapan langsung. Memungkinkan kontak langsung dan interaktif antara dua atau lebih orang. Setiap pihak dapat menelaah kebutuhan pihak lain secara langsung dan membuat keputusan dengan segera.

b. Persahabatan. Personal Selling memungkinkan bertumbuhnya hubungan antar pribadi, mulai dari hubungan bisnis sampai pada hubungan pribadi yang dekat. Para sales representative yang efektif pada umumnya dapat membina hubungan jangka panjang dengan para pelanggannya. Oleh itulah sebabnya, mengapa para tenaga penjual yang berpengalaman banyak dicari perusahaan sebab biasannya mereka sudah memiliki pelanggan tetap.

c. Respons. Penjualan personal mengkondisikan pembeli dalam situasi wajib mendengarkan penjelasan sales representative. Sebab, mendengarkan orang lain saat berbicara, merupakan bagian dari etika komunikasi (sopan).
Penjualan personal atau personal selling merupakan elemen terakhir dari bauran promosi atau promotion mix. Penjualan personal atau personal selling yaitu suatu bentuk komunikasi langsung antara seorang penjual dengan calon pembelinya (person to person communication). Dalam hal ini, penjual berupaya untuk membantu atau mempersuasif calon pembeli untuk membeli produk yang ditawarkan. Tidak seperti iklan, penjualan personal melibatkan interaksi langsung anatara penjual dan pembeli, baik secara tatap muka ataupun melalui alat komunikasi seperti telepon. Melalui interaksi secara langsung ini, maka pihak penjual dapat melihat dan mendengarkan tanggapan atau respon pembeli. Dalam hal ini, penjual dapat langsung memodifikasi informasi yang harus disampaikannya setelah menerima tanggapan dari calon pembeli (Morissan, 2015:34).

Penjelasan di atas selaras dengan apa yang disampaikan oleh Moriarty dkk. Menurut Moriarty dkk (2015:54), istilah penjualan personal 
ini adalah dengan cara menggunakan kontak tatap muka antara pemasar dan calon konsumen. Berbeda dengan kebanyakan advertising, yang efeknya tidak langsung. Penjualan personal juga digunakan dalam pemasaran business to business untuk menjangkau para pihak pembuat keputusan pembelian disuatu bisnis. Menurut Kotler dan Amstrong (2008:201) mengatakan secara lebih luas tentang langkah utama dalam penjualan efektif, langkah-langkah utama yang diikuti tenaga penjual ketika melakukan penjualan meliputi :

1. Memilih dan menilai prospek

Memilih dan menilai prospek (prospecting) merupakan suatu langkah awal dalam proses penjualan dimana tenaga penjual mengidentifikasi pelanggan yang berpotensi beli. Pendekatan terhadap pelanggan potensial yang benar sangat penting bagi keberhasilan. Seorang tenaga penjual harus sering mendekati banyak prospek hanya untuk mendapatkan beberapa penjualan, tenaga penjual juga harus tahu cara menilai (qualify) arahan yaitu, cara mengidentifikasi arahan yang baik dan menyingkirkan arahan yang buruk. Prospek dapat dinilai dan dikategorikan dengan melihat kemampuan beli mereka, volume bisnis, kebutuhan khusus, lokasi, serta kemungkinan.

\section{Prapendekatan}

Langkah tenaga penjual dalam prapendekatan (preapproach) yaitu langkah dalam proses penjualan dimana tenaga penjual belajar sebanyak mungkin tentang pelanggan prospektif sebelum melakukan kunjungan penjualan. Tenaga penjual harus menetapkan tujuan kunjungan, yang mungkin untuk menganalisa prospek, mengumpulkan informasi, dan juga melakukan penjualan segera.

\section{Pendekatan}

Pendekatan (approach) ini merupakan langkah selanjutnya dalam proses penjualan dimana tenaga penjual bertemu dengan pelanggan untuk pertama kalinya dan memulai hubungan dengan baik. Langkah ini membuthkan penampilan diri pribadi yang baik, kalimat pembuka, serta catatan untuk tindak lanjut. Kalimat pembuka harus baik untuk membangun itikad 
baik dari permulaan hubungan. Pembukaan ini dapat diikuti oleh sejumlah pertanyaan kunci untuk paham lebih banyak tentang kebutuhan pelanggan atau dengan memperlihatkan tampilan atau sampel untuk menarik perhatian dan keingintahuan pembeli. Seperti seluruh tahap proses penjualan, mendengarkan prospek merupakan hal penting.

4. Presentasi dan Demontrasi

Dalam proses ini tenaga penjual menceritakan segala hal tentang produk kepada pembeli, menekankan manfaat produk bagi pelanggan. Tenaga penjual mencari solusi lebih yang sesuai dengan konsep pemasaran saat ini. Tenaga penjual yang gigih menjual atau tenaga penjual murah senyum dan ramah. Mereka menginginkan tenaga penjual yang mendengarkan kekhawatiran mereka, memahami kebutuhan mereka, dan merespons produk dan jasa yang benar. Pendekatan kebutuhan-kebutuhan ini memerlukan satu keahlihan mendengarkan dan menyelesaikan masalah yang smart.

5. Mengatasi Keberatan
Mengatasi keberatan adalah dimana seorang tenaga penjual mencari, mengklarifikasi dan mengatasi keberatan pelanggan untuk membeli. Dalam mengatasi keberatan (handling objection), tenaga penjual ini harus bisa menggunakan pendekatan smart, mencari keberatan tersembunyi, meminta pembeli mengklarifikasi semua keberatan, menganggap keberatan sebagai kesempatan untuk menyediakan lebih banyak informasi, dan dapat mengubah keberatan menjadi alasan membeli. Semua tenaga penjual memerlukan pelatihan, keahlihan untuk bisa mengatasi keberatan.

6. Penutupan

Penutupan (closing) dimana tenaga kerja meminta pelanggan mengajukan pesanan. Tenaga penjual harus tahu caranya memahami tanda penutupan dari pembeli, termasuk gerakan fisik, pertanyaan atau komentar. Tenaga penjual juga bisa menggunakan satu dari beberapa teknik penutupan.

7. Tindak Lanjut

Dalam langkah ini proses penjualan dimana tenaga penjual 
menindaklanjuti setelah penjualan untuk memastikan kepuasaan pelanggan dan mengulangi bisnis. Tepat setelah menutup penjualan, tenaga penjual harus melengkapi berbagai detail tentang waktu pengiriman, berbagai persyaratan pembelian, dan masalah lain. Tenaga penjual kemudian harus menjadwalkan pertemuan tindak lanjut ketika pesanan awal diterima, untuk memastikan adanya suatu pelayanan yang baik dan benar.

\subsection{Strategi Pemasaran}

Tangkilisan (2007:252) berkata strategi merupakan penyesuaian institusi, organisasi, atau badan pemerintahan terhadap perubahan lingkungan diluarnya. Institusi atau organisasi yang tidak dapat menyesuaikan diri dengan perubahan yang terjadi pada lingkungan luar akan mengalami kemerosotan atau kegagalan. Strategi adalah upaya pengembangan suatu keunggulan

\section{METODE PENELITIAN}

Metode penelitian ini menggunakan metode kualitatif studi kasus dengan cara mendeskripsikan organisasi atau institusi dalam lingkungan eksternal yang kompetitif untuk pencapaian tujuan atau sasaran organisasi. Strategi juga dibutuhkan karena adanya perkembangan dari masyarakat, kemajuan teknologi, juga tuntutan pasar secara umum.

Menurut Raharjo dan Rinawati (2019:40) strategi pemasaran adalah serangkaian tujuan serta juga sasarannya, kebijakan, dan aturan yang memberi arah kepada usahausaha pemasaran perusahaan dari waktu ke waktu, pada masingmasing tingkatan dan acuan serta alokasinya, paling penting adalah sebagai tanggapan perusahaan dalam berurusan dengan lingkungan dan situasi persaingan yang memang tidak bisa menentu. Dengan kata lain, strategi pemasaran yang berhasil merupakan cara yang melaksanakan konsep pemasarannya yang harus bisa berorientasi kepada prospek atau pelanggan.

apa yang dilakukan oleh CV Surya Gemilang Motor Cabang Wuluhan dalam menerapkan personal selling. 
Teknik penentuan informan menggunakan metode purposive, informan untuk penelitian ini berjumlah 3 orang yang dipilih peneliti karena memiliki kompetensi dibidangnya.
Pengumpulan data dilakukan melalui observasi, wawancara, dan dokumentasi. Metode analisis data dilakukan dengan tiga cara yaitu Data Condensation, Data Display, dan Conclusion Drawing atau Verifications.

\section{HASIL PENELITIAN DAN PEMBAHASAN}

CV Surya Gemilang Motor Cabang Wuluhan bukanlah dealer besar yang memiliki struktur organisasi rumit. Dealer ini adalah cabang kecil (pos) yang hanya di isi oleh 1 koordinator sales dan 4 seorang sales lapangan. Terlepas dari banyak atau sedikitnya seorang sales yang bekerja di CV Surya Gemilang Motor, dalam melakukan penjualan motor honda maka seorang sales adalah alat utama untuk melakukan personal selling.

Pada CV Surya Gemilang Motor Cabang Wuluhan aktivitas sales adalah ujung tombak untuk melakukan penjualan dealer. Kemampuan berjualan sales merupakan suatu kunci dari keberlangsungan dealer. Profit yang di dapat dealer sangat tergantung dari tingkat penjualan oleh seorang sales.
Semakin banyak unit motor yang dijual oleh seorang sales maka akan semakin besar juga pendapatan yang diperoleh dealer, begitu juga dengan sebaliknya.

Strategi atau cara menjual motor itulah yang dinamakan dengan personal selling. Menurut Kotler dan Armstrong (2008:201) langkahlangkah utama yang diterapkan tenaga penjual ketika melakukan penjualan meliputi memilih dan menilai prospek, prapendekatan, pendekatan, presentasi/demontrasi, mengatasi keberatan, penutupan, dan tindak lanjut.

\subsection{Cara Memilih dan Menilai Prospek}

Strategi memilih dan menilai prospek merupakan langkah awal dalam melakukkan kegiatan personal 
selling. Para sales lapangan CV Surya Gemilang Motor Cabang Wuluhan dalam melakukan proses penjualan personal menggunakan cara tersebut.

Sales lapangan dalam memilih prospek yang potensial dengan cara melakukan kanvas. Kanvas adalah kegiatan mendatangi suatu tempat keramaian (pasar, alun-alun, pusat perbelanjaan, dan sebagainya) untuk melakukan penawaran unit kepada konsumen secara acak. Sales juga membagi-bagikan brosur kepada setiap calon konsumen yang ditemui. Tidak ada target konsumen kusus dalam kegiatan kanvas. Kanvas bisa dilakukan secara bersama-sama maupun dilakukan sendiri/pribadi. Para sales memilih konsumen secara acak. Dalam 1 bulan rata-rata sales lapangan melakukan kanvas bersama 4 kali, atau dilakukan seminggu sekali.

Tujuan kanvas dilakukan adalah mencari konsumen secara acak. Sales lapangan memberikan brosur dan nomor telfon kepada setiap orang yang ditemui. Kegiatan ini adalah salah satu cara yang digunakan untuk memilih konsumen dan melakukan penilaian apakah orang yang ditemui tersebut tertarik untuk membeli atau tidak.

Pada saat sales membagibagikan brosur dan melakukan penawaran kepada orang yang ditemui dalam kegiatan kanvas. Maka sales akan mengetahui mana prospek yang tertarik atau tidak. Disinilah proses menilai konsumen dilakukan oleh sales CV Surya Gemilang Motor Cabang Wuluhan. Orang yang memiliki ketertarikan untuk membeli motor honda maka akan merespon lebih baik dari pada orang yang tidak memiliki niat untuk membeli.

Sales akan menilai bahwa orang yang merespon penawaran yang dilakukan akan membeli motor honda. Meskipun tidak selalu dengan waktu yang cepat, akan tetapi dikemudian hari orang tersebut akan membeli motor. Sales sudah mengerti dan dapat menilai orang yang tertarik tersebut.

Langkah selanjutnya sales CV Surya Gemilang Motor Cabang Wuluhan dalam memilih prospek adalah dengan cara menghubungi konsumen lama mereka atau 
kenalan-kenalan mereka. Sales lebih dalam, seorang sales menawarkan motor dengan cara mendatangi kerumahnya atau dengan menelfon (jika sudah memiliki nomor telepon). Sales menawarkan apakah membutuhkan motor honda atau tidak. Memilih untuk menghubungi orang-orang yang sudah dikenal adalah kegiatan yang biasa dilakukan oleh sales ketika tidak sedang melakukan kanvas. Dalam melakukan kegiatan tersebut sales juga bisa menilai mana orangorang yang serius menginginkan pembelian motor honda. Ketika sales sudah dapat menilai bahwa ada kemungkinan ketertarikan untuk melakukan pembelian motor honda, barulah sales akan melakukan pra pendekatan kepada orang tersebut.

\subsection{Pra Pendekatan Yang}

\section{Dilakukan Sales}

Pada tahap pra pendekatan ini yang dilakukan oleh para sales CV Surya Gemilang Motor Cabang Wuluhan adalah mempelajari informasi-informasi tentang calon konsumen tersebut. Sales sebelum melakukan pendekatan untuk bisa masuk menawarkan produk honda 
pembuka dengan sejumlah kalimat pertanyaan kunci untuk mengetahui lebih banyak lagi tentang keinginan atau kebutuhan calon konsumen. Pendekatan adalah tahap sebelum sales melakukan presentasi untuk menawarkan produk honda.

Pendekatan sangat penting dilakukan oleh sales sebelum mereka melakukan presentasi tentang produk honda. Karena dengan melakukan pendekatan, sales akan memahami keinginan dari konsumen. Keinginan konsumen merupakan salah satu hal dalam pemasaran suatu produk yang cukup sulit untuk dipahami. Produk seperti apa yang disukai konsumen, apa yang tidak mereka sukai dari produk, berapa harga yang diinginkan konsumen, dan masih banyak pertanyaan-pertanyaan yang perlu dijawab dari konsumen. Setelah proses pendekatan sudah di rasa cukup, baru sales melakukan presentasi.

\subsection{Tahap Presentasi dan} Demontrasi Yang Dilakukan

Sales CV Surya Gemilang Motor Cabang Wuluhan setelah melakukann pendekatan kepada prospek, langkah selanjutnya adalah presentasi. Setelah menjadi pendengar yang baik dalam tahap pendekatan, pada tahap presentasi ini para sales lebih berbicara banyak tentang keunggulan dari produk honda yang ditawarkan.

Motor honda memang memiliki banyak keunggulan. Oleh karena itu sales CV Surya Gemilang Motor Cabang Wuluhan selalu mempresentasikan keunggulan tersebut. Berdasarkan keterangan koordinator sales Heru Mustofa dan sales lapangan Fauzi Hasan di atas secara garis besar keunggulan yang dipresentasikan kepada prospek (calon konsumen) diantaranya irit bahan bakar, kualitas produk bagus, perawatan yang mudah, suku cadang lebih murah, purna jual yang stabil, dan tersedia banyak pilihan produk.

Tahap ini adalah waktu seorang sales melakukan komunikasi persuasif kepada konsumen. Dengan berbicara banyak keunggulan produk honda, diharapkan konsumen tertarik dan bersedia membeli motor.

\subsection{Tahap Ketika Mengatasi} Keberatan (Handling Objection) 
Sales untuk melakukan handling objection menggunakan pendekatan yang soft. Sales akan mengatasi keberatan dengan sangat hati-hati. Faktor yang menjadi penyebab ratarata konsumen CV Surya Gemilang Motor keberatan adalah masalah harga. Padahal harga motor honda didealer lain (Kabupaten Jember) relatif sama tidak ada perbedaan jauh. Harga sudah ditentukan oleh honda pusat sehingga dealer tidak bisa menjual dengan harga sembarangan.

Penerapan cara mengatasi keberatan harga dari konsumen adalah dengan cara memberikan informasi bahwa sebenarnya harga motor honda sudah ditetapkan oleh pusat. Ketika konsumen tetap kukuh menawar harga, maka strategi yang dilakukan oleh sales CV Surya Gemilang Motor Cabang Wuluhan adalah memberikan potongan. Dealer dapat memberikan potongan harga kepada konsumen antara Rp 100.000 sampai dengan Rp 500.000 jika melakukan pembelian tunai. Strategi potongan harga ini menjadi solusi bagi sales agar konsumen menerima dan sepakat melakukan pembelian.

\subsection{Cara Menutup Penawaran (Sales Closing)}

Tahap sales closing pada dasarnya merupakan tahap dimana seorang sales mendapatkan hasil jawaban dari prospek (calon konsumen). Apakah konsumen tertarik membeli atau tidak. Dua kemungkinan tadi harus dapat dipahami bagi sales. Penutupan yang berhasil adalah ketika prospek bersepakat untuk membeli motor honda. Ketika konsumen sudah sepakat untuk membeli motor honda, maka sales akan menyiapkan syaratsyarat pembelian dan meminta konsumen untuk bisa melakukan pembayaran. Tetapi manakala prospek belum tertarik untuk melakukan pembelian maka langkah selanjutnya seorang sales adalah melakukan tindak lanjut atau penawaran ulang dikemudian hari.

Cara melakukan penawaran adalah dengan mengajukan pertanyaan kepada konsumen. Pertanyaan yang disampaikan apakah bersedia membeli atau tidak. Sales melakukan komunikasi persuasif kepada prospek (calon konsumen) 
untuk mempengaruhi agar bersedia membeli motor honda.

\subsection{Tindak Lanjut (Follow Up)} Yang Dilakukan sales

Strategi dealer CV Surya Gemilang Motor Cabang Wuluhan dalam melakukan tindak lanjut juga ada 2 cara. Cara yang pertama adalah tindak lanjut ketika penjualan sudah berhasil dilakukan, dan cara kedua adalah ketika gagal.

Langkah sales ketika baru saja melakukan presentasi dan ternyata konsumen deal untuk membeli produk honda adalah menyiapkan motor yang ingin dibeli. Sales meminta konsumen untuk melakukan pembayaran di dealer. Setelah itu sales akan melakukan pemesanan order kepada dealer Surya Gemilang Motor cabang Jember untuk melakukan pengiriman langsung kerumah konsumen. Biasanya prosesnya hanya menunggu 2 jam untuk diproses melakukan pengiriman. Tetapi jika keadaan dealer Surya Gemilang Motor Jember banyak pesanan (pembelian), maka motor akan bisa dikirim paling lama 1 hari. Itupun jika motor yang dipesan stocknya ada. Karena keterbatasan armada pengiriman yang tidak bisa dilakukan setiap waktu.

Beberapa waktu kemudian sales CV Surya Gemilang Motor Cabang Wuluhan juga melakukan tindak lanjut dengan menanyakan keluhan atau kepuasan. Sales akan intens mengingatkan service motor rutin setiap bulan. Ini adalah bentuk tindak lanjut yang dilakukan oleh sales. Ketika STNK/BPKB motor sudah jadi, maka sales lapangan akan mengantar langsung kerumah konsumen. Konsumen tidak perlu repot untuk datang ke dealer mengambil STNK. Sales melakukan hal tersebut sebagai bentuk tindak lanjut atau sebagai bentuk pelayanan setelah pembelian.

Tindak lanjut tersebut adalah proses ketika personal selling berhasil, tetapi jika proses personal selling belum berhasil, maka cara melakukan tindak lanjut berbeda. Sales CV Surya Gemilang Motor Cabang Wuluhan dalam waktu dekat akan kembali menghubungi konsumen untuk melakukan penawaran ulang. Jika konsumen 
masih belum bersedia untuk membeli, maka sales tidak putus asa. Sales tetap akan menjalin hubungan yang baik dengan prospek (calon pelanggan) tersebut. Karena suatu

\section{KESIMPULAN DAN SARAN}

\subsection{Kesimpulan}

Kesimpulan yang diperoleh sebagai berikut:

1. Cara memilih dan menilai prospek dilakukan dengan cara melakukan kanvas. Baik dilakukan secara bersama-sama maupun dilakukan secara pribadi. Memilih prospek juga dilakukan dengan cara menghubungi orang-orang yang sudah dikenal atau konsumen lama. Dari proses memilih prospek tersebut, sales bisa menilai konsumen yang tertarik atau tidak.

2. Pra pendekatan yang dilakukan sales dengan mencari sebanyakbanyaknya informasi tentang konsumen.

3. Langkah Pendekatan dilakukan dengan tatap muka dan komunikasi langsung. Pendekatan dilakukan dengan saat jika konsumen tersebut membutuhkan motor tidak menutup kemungkinan untuk menghubungi sales CV Surya Gemilang Motor Cabang Wuluhan.

mengenal lebih dalam keinginan dan kebutuhan dari konsumen.

4. Tahap Presentasi dan Demontrasi Yang dilakukan dengan cara mengatakan tentang keunggulan-keunggulan dari motor honda agar konsumen tertarik.

5. Tahap Ketika Mengatasi Keberatan (Handling Objection) dengan cara memberikan potongan harga, karena mayoritas konsumen keberatan dengan harga.

6. Cara Menutup Penawaran (Sales Closing) adalah dengan memberikan pertanyaan kepada konsumen apakah bersedia untuk membeli.

7. Tindak Lanjut (Follow Up) Yang Dilakukan sales ada 2, pertama adalah tindak lanjut ketika penjualan berhasil, dan yang kedua adalah tindak lanjut 
ketika penjualan belum berhasil/gagal. Sales akan menyiapkan motor untuk segera dikirim kerumah konsumen jika penawaran berhasil, lalu mengingatkan service berkala kepada konsumen serta mengantar STNK/BPKB ketika sudah selesai. Langkah tindak lanjut ketika terjadi gagal transaksi pembelian adalah melakukan penawaran ulang dikemudia hari.

\subsection{Saran}

1. Bagi perusahaan hendaknya menambah jumlah sales menjadi 7 orang agar target penjualan dapat tercapai.

2. Bagi akademisi selanjutnya bahwa penelitian ini hanya sebatas tentang personal selling. Peneliti selanjutnya bisa melakukan penelitian dibidang lainnya. CV Surya Gemilang Motor Cabang Wuluhan bisa dikaji dari sisi kepemimpinan, pelayanannya, keuangan, dan sebagainya.

\section{DAFTAR PUSTAKA}

Alma, Buchari. 2014. Kewirausahaan. Bandung : Alfabeta.

Cannon, Joseph, William Perrcault, dan Jerome McCarthy. 2009. Pemasaran Dasar 2. Edisi 16, buku ke-2. Jakarta : Salemba Empat.

Cannon, Joseph. William, dan Jerome McCarthy. 2008. Pemasaran Dasar. Edisi 16, buku ke-1. Jakarta : Salemba Empat.

Handini, Sri, Sukesi dan Hartati K Astuti. 2019. Pemberdayaan Masyarakat Desa Dalam Pengembangan UMKM di Wilayah Pesisir. Surabaya : Scopindo Media Pustaka.
Herujito, M. Yayat. 2001. Dasar Dasar Manajemen. Bogor : Grasindo.

Kotler, Philip dan Gary Armstrong. 2008. Prinsip-Prinsip Pemasaran. Edisi 12, Jilid ke2. Jakarta : Erlangga.

Moriarty, Sandra, Nancy, dan William Wells. 2015. Advertising. Edisi 8. Jakarta : Prenadamedia Group.

Morissan. 2010. Komunikasi Pemasaran Terpadu. Jakarta : Prenadamedia Group.

Porter, E. Michael. 1994. Keunggulan Bersaing. Jakarta : Binarupa Aksara.

Raharjo, T Weda, Rinawati, Septa. 2019. Penguatan Strategi Pemasaran dan Daya Saing UMKM Berbasis Kemitraan 
Desa Wisata. Surabaya : CV JPS.

Simamora, Bilson. 2003. Memenangkan Pasar Dengan Pemasaran Efektif dan Profitabel. Jakarta : PT. Gramedia Pustaka Utama.

Stanton, William. 1989. Prinsip Pemasaran. Jakarta : Erlangga.

Sudarsono, Heri. 2019. Manajemen Pemasaran. Jember : CV Pustaka Abadi
Suryani, Tatik. 2017. Manajemen Pemasaran Strategik Bank di Era Global. Jakarta : Prenadamedia Group.

Suwarno. 2011. Manajemen Pemasaran Jasa Perusahaan Pelayaran. Edisi 2. Semarang : CV. Indoprint.

Tangkilisan, Hessel. 2007. Manajemen Publik. Jakarta : Grasindo. 